\title{
QUALITY OF LIFE AND MENTAL EMOTIONAL HEALTH OF ELDERLY PEOPLE
}

\author{
Alfrina Hany ${ }^{1}$ \\ ${ }^{1}$ Nursing School, Faculty of Medicine Universitas Brawijaya
}

\begin{abstract}
The higher dependence rate of elderly people in Ponorogo can make their quality of life lower.Unfortunately, how the quality of life can influence the mental emotional health is still unknown. The purpose of this research was to identify the influence of the quality of life to mental emotional disorders of older adults. The design of this research was Observational correlational with cross sectional approach. This research was held at 4 working areas of health facilities in Ponorogo district in East Java from March to May in 2015. This study included 200 elder people as participants and 50 sampling quota in each health facilities. The data collection in this study was assessed with 2 instruments. First instrument was used in this study developed by World Health Organization in Quality of life (WHO QOL-BREF) and second instrument was Self Reporting Questionnaire (SRQ). The Pearson Correlation test was performed in this study (SPSS version 20). The researchers found out that there was an influence of quality of life (physical health, psychologic, social relationship, and environment) on mental emotional disorders in elder people ( $p$-Value $<0.05)$. This result revealed that quality of life in older adults influenced the mental emotional disorders. The improvement actions that can be proposed to decrease the mental emotional disorders of the elderly are the elderly are able to have an easy and quick access to health and general service facilities to support the mental well being of older people.
\end{abstract}

Keywords: mental emotional health, elderly people, quality of life

\begin{abstract}
ABSTRAK
Peningkatan angka ketergantungan kelompok usia lanjut (lansia) di Ponorogo menyebabkan penurunan kualitas hidup lansia. Namun belum diketahui apakah kualitas hidup lansia berpengaruh terhadap kesehatan mental emosionalnya. Tujuan penelitian ini adalah untuk mengidentifikasi pengaruh kualitas hidup terhadap kesehatan mental emosional pada lansia. Desain penelitian menggunakan observasional analitik dengan pendekatan cross sectional. Penelitian ini dilakukan di empat wilayah kerja puskesmas kabupaten Ponorogo pada bulan Maret - Mei Tahun 2015. Jumlah sampel penelitian sebanyak 200 responden menggunakan sampling kuota sebesar 50 responden yang mewakili masing-masing puskesmas. Metode pengumpulan data pada penelitian ini dengan wawancara menggunakan dua instrumen yaitu instrumen kualitas hidup (WHOQOL-BREF) dan instrument kesehatan mental emosional dinilai dengan Self Reporting Questionnaire (SRQ). Uji statistic menggunakan uji Pearson Correlation (Spss versi 16). Hasil penelitian ini diketahui ada pengaruh antara kualitas hidup (kesehatan fisik; psikologis; hubungan social; dan lingkungan) dengan kesehatan mental emosional lansia (nilai $p<0,05$ ). Pada penelitian ini menunjukkan bahwa kualitas hidup lansia mempengaruhi kesehatan mental emosional lansia. Upaya yang dapat dilakukan untuk meningkatkan kesehatan mental emosional lansia meliputi kemudahan lansia untuk mendapatkan akses terhadap pelayanan kesehatan dan kesejahteraan sehingga kesehatan mental lansia akan semakin membaik.
\end{abstract}

Kata Kunci: kesehatan mental emosional, kualitas hidup, lanjut usia.

Jurnal Ilmu Keperawatan, Vol. 6, No. 1 Mei 2018; Korespondensi : Alfrina Hany. Program Studi IImu Keperawatan FK UB Malang. Jl. Veteran Malang, Kode Pos 65144. .Email : alfrina_hany@yahoo.com Telp. 081805059292 


\section{PENDAHULUAN}

Jumlah lansia di Indonesia pada tahun 2014 mencapai 20,24 juta jiwa, setara dengan $8,03 \%$ dari seluruh penduduk Indonesia (BPS, 2015). Populasi lansia di Jawa Timur sebesar $10,69 \%$ dari keseluruhan penduduk (BPS, 2014). Peningkatan usia pada lansia berdampak terhadap masalah kesehatan mental emosional.

\section{World Health Organization} menyatakan bahwa sebanyak $15 \%$ dari orang dewasa yang berusia lebih dari sama dengan 60 tahun mengalami gangguan mental dan $6.6 \%$ dari ganguan ini dapat menyebabkan disabilitas. Gangguan pada kesehatan mental emosional dapat menyebabkan dampak bagi lansia, antara lain dapat menurunkan kemampuan lansia dalam melakukan aktivitas sehari-hari, menurunkan kemandirian dan kualitas hidup lansia.

Tingginya prevalensi dan dampak yang timbul akibat masalah kesehatan mental pada lansia memerlukan upaya khusus penanganannya. Upaya penanganan masalah kesehatan mental dapat dilakukan secara efektif apabila dapat mengatasi faktor-faktor yang berhubungan dengan gangguan kesehatan mental pada lansia.

Kabupaten Ponorogo pada tahun 2014 termasuk dalam proporsi paling tinggi ketiga dalam jumlah lansia yaitu sebesar 15,92\% dengan rasio ketergantungan lansia sebesar $25,60 \%$, mengalami keluhan kesehatan sebesar $51,53 \%$, angka kesakitan sebesar 19,60\% (BPS Jawa Timur, 2014). Penelitian tentang kualitas hidup dan kesehatan mental pada lansia di Kabupaten Ponorogo belum pernah dilakukan sehingga peneliti tertarik untuk melakukan penelitian ini. Penelitian ini bertujuan untuk mengidentifikasi kualitas hidup lansia dan kesehatan mental lansia serta pengaruh antara kualitas hidup lansia (kesehatan fisik; psikologis; hubungan sosial; dan lingkungan) terhadap kesehatan mental lansia.

\section{METODE}

\section{Desain}

Jenis penelitian ini adalah observasional analitik dengan desain cross sectional. Penelitian ini dilakukan di Kabupaten Ponorogo, khususnya di empat wilayah kerja Puskesmas pada bulan Maret-April 2015. Pengambilan sampel dalam penelitian ini menggunakan kuota sampling sebanyak 200 responden di masing-masing wilayah kerja puskesmas sebanyak 50 responden. Kriteria inklusi adalah seluruh lansia yang berada di wilayah kerja puskesmas yang berusia lebih dari 60 tahun. Kriteria eksklusinya adalah lansia yang tidak memberikan kesediaan untuk menjadi responden.

\section{Kuisioner}

Instrumen penelitian kualitas hidup menggunakan kuisioner kualitas hidup (WHOQOL-BREF) sebanyak 23 pertanyaan (kesehatan fisik sebanyak 7 item pertanyaan, psikologis sebanyak 6 item pertanyaan, hubungan sosial sebanyak 3 item pertanyaan, dan lingkungan sebanyak 7 item pertanyaan). Masing-masing item pertanyaan diberi skor 0 : tidak pernah; 1: jarang; 2: sering; 3: selalu. Skor total instrument kualitas hidup lansia (minimal $=0$, maksimal=69), kesehatan fisik (minimal=0, maksimal 21), psikologis (minimal=0, maksimal=18), hubungan sosial (minimal=0, maksimal=9), dan lingkungan (minimal=0, maksimal=21). Sedangkan kuisioner kesehatan 
mental emosional dinilai dengan Self Reporting Questionnaire (SRQ) yang terdiri dari 20 item pertanyaan dengan pilihan jawaban ya artinya mengalami gangguan (skor=1) atau tidak mengalami gangguan (skor=2) sehingga skor total kesehatan mental emosional lansia yang minimal=20 dan maksimal=40. Pengaruh kualitas hidup lansia (kesehatan fisik, psikologis, hubungan sosial dan lingkungan) terhadap kesehatan mental emosional lansia dianalisis dengan uji Pearson Correlation (Spss versi 16).

\section{HASIL PENELITIAN}

Karakteristik responden berdasarkan jenis kelamin, usia, pendidikan, pekerjaan dan status perkawinan dijelaskan pada tabel 1.

Tabel 1. Karakteristik Lansia Berdasarkan Jenis Kelamin, Usia, Pendidikan, Pekerjaan dan Status perkawinan di 4 Wilayah Kerja Puskesmas Kabupaten Ponorogo Tahun $2015(n=200)$

\begin{tabular}{|c|c|c|}
\hline Karakteristik Lansia & Frekuensi & Prosentase \\
\hline \multicolumn{3}{|l|}{ Jenis Kelamin } \\
\hline - Laki-laki & 45 & 22,5 \\
\hline - $\quad$ Perempuan & 155 & 77,5 \\
\hline \multicolumn{3}{|l|}{ Usia } \\
\hline - 60-65 Tahun & 68 & 34 \\
\hline - >65 Tahun & 132 & 66 \\
\hline \multicolumn{3}{|l|}{ Pendidikan } \\
\hline - $\quad$ Tidak Sekolah & 95 & 47,5 \\
\hline - $\quad$ SD & 96 & 48 \\
\hline - SMP & 9 & 4,5 \\
\hline - SMA & 0 & 0 \\
\hline \multicolumn{3}{|l|}{ Pekerjaan } \\
\hline - Tani & 106 & 53 \\
\hline - $\quad$ Pedagang & 38 & 19 \\
\hline - Swasta & 6 & 3 \\
\hline - $\quad$ Tidak tetap & 23 & 11,5 \\
\hline - $\quad$ Tidak bekerja & 27 & 13,5 \\
\hline \multicolumn{3}{|l|}{ Status Perkawinan } \\
\hline - Menikah & 54 & 27 \\
\hline - Janda & 124 & 62 \\
\hline - $\quad$ Duda & 22 & 11 \\
\hline
\end{tabular}

Dari Tabel 1 di atas dapat dilihat bahwa dari data demografi, jumlah responden perempuan lebih banyak dibandingkan lakilaki, sebagian besar berusia $>65$ tahun, latar belakang pendidikan responden kebanyakan pendidikan dasar, sebagian besar berprofesi sebagai petani, dan kebanyakan mempunyai status pernikahan janda.

Data tentang persepsi kualitas hidup lansia (kesehatan fisik, psikologis, hubungan sosial dan lingkungan) dan kesehatan mental emosional lansia dapat dilihat di Tabel 2.

Tabel 2. Persepsi Responden Terhadap Kualitas Hidup dan Gangguan Mental Emosional Lansia di 4 Wilayah Kerja Puskesmas Kabupaten Ponorogo Tahun $2015(n=200)$

\begin{tabular}{|c|c|c|c|c|}
\hline Variabel & Median* & SD & $\begin{array}{c}\text { Skor Min - } \\
\text { Skor Maksimal }\end{array}$ & $\begin{array}{c}95 \% \\
\text { Cl }\end{array}$ \\
\hline $\begin{array}{l}\text { Kesehatan } \\
\text { Mental }\end{array}$ & 23 & 4,8 & $20-39$ & $\begin{array}{l}24,2- \\
25,5\end{array}$ \\
\hline $\begin{array}{l}\text { Kualitas } \\
\text { Hidup } \\
\text { Lansia: }\end{array}$ & 37 & 4,9 & $24-46$ & $\begin{array}{l}35,7- \\
37,1\end{array}$ \\
\hline $\begin{array}{l}\text { Kesehatan } \\
\text { Fisik }\end{array}$ & 10 & 1,9 & $7-14$ & $\begin{array}{l}10,2- \\
10,7\end{array}$ \\
\hline Psikologi & 9 & 1,9 & $6-12$ & $\begin{array}{l}9,3- \\
9,9\end{array}$ \\
\hline $\begin{array}{l}\text { Hubungan } \\
\text { Sosial }\end{array}$ & 6 & 0,9 & $3-6$ & $\begin{array}{c}5,3- \\
5,5\end{array}$ \\
\hline Lingkungan & 10 & 1,9 & $7-14$ & $\begin{array}{l}10,7- \\
11,2\end{array}$ \\
\hline
\end{tabular}

Berdasarkan data pada tabel 2 dapat diprediksi dengan menggunakan tingkat kepercayaan 95\% skor kesehatan mental emosional yang dipersepsikan oleh lansia skornya berkisar antara 24,2-25,5 yang artinya skor kesehatan mental emosional lansia lebih besar dari skor nilai mediannya yaitu 23 tetapi masih sangat kurang jika dibandingkan dengan nilai maksimal kesehatan mental yaitu 39, sedangkan skor total kualitas hidup lansia berkisar antara 
35,7-37,1. Skor sub variable kualitas hidup meliputi kesehatan fisik skornya berkisar antara 10,2-10,7; Psikologi skornya antara 9,3-9,9; Hubungan social skornya berkisar antara 5,3-5,5; dan Lingkungan skornya berkisar antara 10,7-11,2, hasil ini menunjukka masih perlu adanya peningkatan skor kualitas hidup lansia di Kabupaten Ponorogo.

Uji Pearson Correlation antara kualitas hidup lansia (kesehatan fisik, psikologis, hubungan social, dan lingkungan) dengan kesehatan mental emosional lansia dapat dilihat pada Tabel 3.

Tabel 3. Hasil Analisis Hubungan Kualitas Hidup Lansia dengan Kesehatan Mental Emosional Lansia di 4 Wilayah Kerja Puskesmas Kabupaten Ponorogo Tahun 2015 ( $n=200)$

\begin{tabular}{lcc}
\hline & \multicolumn{2}{c}{$\begin{array}{c}\text { Kesehatan Mental Emosional } \\
\text { Lansia }\end{array}$} \\
\cline { 2 - 3 } & Korelasi (r) & pValue \\
\hline $\begin{array}{l}\text { Kualitas Hidup } \\
\text { (Total) }\end{array}$ & 0,4 & 0,000 \\
\hline Kesehatan Fisik & 0,4 & 0,000 \\
\hline Psikologis & 0,4 & 0,000 \\
\hline Hubungan Sosial & 0,2 & 0,017 \\
\hline Lingkungan & 0,3 & 0,000
\end{tabular}

Berdasarkan Tabel 3 di atas diketahui bahwa kualitas hidup lansia dan semua sub variabelnya memiliki hubungan dengan kesehatan mental emosional lansia ( $p$ Value $<0,05$ ) namun tingkat keeratan hubungan antara total skor kualitas hidup dengan kesehatan mental emosional adalah rendah. Tingkat keeratan hubungan antara skor kesehatan fisik, psikologis dan lingkungan dengan kesehatan mental emosional adalah rendah, sedangkan tingkat keeratan hubungan antara skor hubungan sosial dan gangguan mental emosional adalah sangat rendah. Pola hubungan dalam penelitian ini bersifat positif artinya semakin baik kualitas hidup lansia maka akan semakin baik pula kesehatan mental emosionalnya.

\section{PEMBAHASAN}

Penurunan kualitas hidup lansia terjadi karena adanya perasaan negatif terhadap dirinya, ketergantungan pada orang lain yang terus berlanjut, dan kehilangan otonomi terhadap dirinya (Lasisi \& Gureje, 2013). Penurunan kualitas hidup pada lansia yaitu perubahan fisik, psikologis, emosional dan sosial berdampak terhadap penurunan kemampuan dalam melakukan aktifitas sehari-hari dan mobilitasnya (Moti \& McAuley, 2010; Hudakova \& Hornakova, 2011;Ahmed, Mohamed \& Aly, 2014). Kondisi ini sesuai dengan temuan dalam penelitian ini yaitu dengan tingkat kepercayaan 95\% skor kualitas hidup lansia berada dalam rentang 35,7-37,1 artinya kualitas hidup lansia masih belum optimal karena berada di bawah skor maksimal sebesar 46.

Gangguan mental emosional merupakan suatu keadaan yang menunjukkan adanya perubahan emosional pada individu yang dapat berkembang menjadi keadaan patologis (Idaini et al., 2009). Kondisi ini juga akan mempengaruhi kesehatan mental emosionalnya (Risdianto, 2009). Menurut data Riset Kesehatan Dasar tahun 2013, prevalensi gangguan mental emosional pada lansia lebih tinggi dibandingkan dengan tingkat umur lainnya. Hal ini sesuai dengan penelitian ini yang menunjukkan masih belum maksimalnya skor kesehatan mental lansia (Badan Penelitian dan Pengembangan Kesehatan, 2013). 
Hasil penelitian ini juga menunjukkan ada hubungan antara kualitas hidup dengan kesehatan emosional lansia, semakin kurang baik kualitas hidup maka akan semakin kurang baik juga gangguan emosional pada lansia. Upaya yang dapat dilakukan untuk mengelola kualitas hidup lansia agar semakin baik adalah melalui kemudahan lansia untuk memperoleh akses terhadap pelayanan kesehatan dan kesejahteraan.

Gangguan masalah kesehatan dan ketidakmandirian fisik sering terjadi pada lansia yang disebabkan adanya berbagai penyakit di dalam tubuh, maupun dikarenakan akibat dari terjadinya proses menua. Berdasarkan hasil penelitian ditemukan data bahwa ada pengaruh antara kesehatan fisik lansia terhadap gangguan emosional lansia dengan tingkat keeratan sedang dan pola hubungan yang positif, artinya semakin kurang baik kesehatan fisik akan berpengaruh terhadap semakin kurang baiknya gangguan emosional pada lansia. Hasil penelitian ini sejalan dengan penelitian yang dilakukan oleh Suyoko (2012) dan Qonitah dan Isfandiari (2015) yang menyebutkan bahwa ada hubungan antara kemandirian fisik dengan gangguan mental emosional pada lansia. Kesehatan mental dapat berpengaruh terhadap kesehatan fisik, begitu pula sebaliknya, sebagai contoh lansia dengan gangguan jantung akan lebih berisiko mengalami gangguan mental dibandingkan lansia yang sehat (WHO, 2017). Hasil penelitian ini juga sesuai dengan penelitian yang dilakukan oleh Sutikno (2015) yang menyebutkan bahwa kesehatan fisik berhubungan secara signifikan dengan kesehatan mental. Upaya yang dapat dilakukan untuk meningkatkan kesehatan fisik adalah kemudahan akses lansia terhadap pelayanan kesehatan sehingga permasalahan kesehatan fisik dapat secara dini terdeteksi dan segera dilakukan penanganan oleh tenaga tenaga kesehatan yang berdampak terhadap berkurangnya komplikasi yang dialami oleh lansia.

Lansia yang mempunyai kemampuan dalam menerima kondisi dirinya dan menikmati kehidupan di masa tua akan mempunyai kualitas hidup yang lebih baik dan menurunkan kemungkinan terjadinya gangguan mental emosional daripada lansia yang tidak mempunyai kemampuan tersebut (Butler \& Ciarrochi, 2007). Hasil penelitian didapatkan adanya pengaruh psikologis terhadap gangguan mental emosional.

Perubahan psikologis berasal dari kesadaran tentang merosotnya dan perasaan rendah diri apabila dibandingkan dengan orang yang lebih muda, kekuatan, kecepatan, dan keterampilan. Kondisi ini sesuai dengan temuan dalam penelitian ini yaitu dengan tingkat kepercayaan $95 \%$ skor kesehatan fisik lansia berada dalam rentang 10,2-10,7 artinya kesehatan fisik lansia masih belum optimal karena berada di bawah skor maksimal sebesar 14, kondisi ini dapat menimbulkan rasa rendah diri yang mengakibatkan produktivitasnya menjadi rendah.. Upaya yang dapat dilakukan untuk memperbaiki faktor psikologi adalah dengan mengadakan pertemuan dalam kelompok lansia dan keluarga membahas tentang kesiapan dalam menghadapi perubahan pada usia lansia.

Hasil penelitian yang dilakukan oleh Cacioppo (2013) menyebutkan bahwa lansia yang memiliki hubungan sosial tidak baik menunjukkan kemampuan kognitif yang 
rendah dan akan berdampak terhadap gangguan mental pada lansia. Hasil ini sesuai dengan temuan pada penelitian ini yaitu ada hubungan antara hubungan sosial terhadap gangguan mental emosional pada lansia, semakin kurang baik hubungan sosial maka akan semakin kurang baiknya juga gangguan mental emosional yang dialami lansia. Upaya yang dapat dilakukan untuk meningkatkan hubungan sosial dapat dilakukan melalui pertemuan dengan teman sebaya dalam Posyandu lansia atau kegiataan keagamaan. Aktivitas spiritualitas dan sosial akan memberikan nilai tertinggi bagi lansia untuk menemukan kebermaknaan dan rasa harga dirinya.

Hasil penelitian Sutikno menyebutkan bahwa kesehatan mental yang tidak baik banyak ditemukan pada lansia yang mempunyai lingkungan yang tidak baik. Hasil penelitian ini juga menunjukkan ada pengaruh lingkungan terhadap gangguan emosional pada lansia, semakin lingkungannya kurang baik maka semakin kurang baiknya gangguan mental emosional yang dialami oleh lansia. Keadaan ekonomi lansia memiliki hubungan dengan kejadian kesehatan mental pada lansa (Minh et al., 2010). Hasil penelitian menunjukkan

\section{DAFTAR PUSTAKA}

Ahmed, H.I.,Mohamed, E.E., \& Aly, A.M (2014). Effect of Mobility on the Quality of Life among Older Adults in

Geriatric Home at Makkah Al-Mukarramah. Advances in Life Science and Technology Vol 17

Badan Penelitian dan Pengembangan Kesehatan, (2013). Riset Kesehatan Dasar Dalam Angka: Riskesdas 2013 Provinsi pada aspek pernyataan lingkungan yang berkaitan dengan kepemilikian uang dinilai tidak baik oleh responden. Upaya yang dapat dilakukan untuk peningkatan lingkungan melalui pembentukan kelompok ketrampilan yang bisa dilakukan oleh lansia dan pemberian pelayanan kesehatan oleh tenaga kesehatan kepada lansia dengan gangguan mental dan keluarganya. Pembentukan lansia yang sadar kesehatan mental di tingkat masyarakat adalah sangat penting untuk dilakukan untuk membentuk lingkungan yang sehat jiwa secara efektif (WHO, 2017).

\section{SIMPULAN}

Kesimpulan dari penelitian ini adalah terdapat hubungan antara kualitas hidup lansia (kesehatan fisik, psikologis, hubungan social, lingkungan) terhadap kesehatan emosional mental pada lansia, namun hubungan tersebut lemah.

Saran yang berikan yaitu perlu dibuat kebijakan agar lansia mudah untuk mengakses pelayanan kesehatan, tersedianya pedoman peningkatan kualitas hidup lansia untuk perawat komunitas dan peningkatan kualitas penelitian dengan menggunakan metode komparatif atau eksperimen.

Jawa Timur, Departemen Kesehatan Republik Indonesia, Jakarta

Badan Pusat Statistik (2015). Statistik Penduduk Lansia 2014: Hasil Survei Sosial Ekonomi Nasional.Badan Pusat Statistik, Jakarta-Indonesia

Badan Pusat Statistik (2014). Profil Penduduk Lanjut Usia Jawa Timur 2013: Hasil Survei Sosial Ekonomi Nasional.Badan Pusat Statistik Provinsi Jawa Timur 
Butler J \& Ciarrochi J (2007). Pschological acceptance and quality of life in the elderly. Quali Life Res 16

Cacioppo JT \& Cacioppo S (2013). Older adults reporting social isolation or loneliness show poorer cognitive function 4 years later. Evid based Nurs Hudakova, A \& Hornakova, A (2011). Mobility and quality of life in elderly and geriatric Patients. International Journal of Nursing and Midwifery Vol.3(7), pp.81-85, July 2011 Available online http://www. academic journals.org/ijnm

Hany, A \& Putra, KR (2015). Hubungan Disabilitas dengan Kualitas Hidup Lansia. Tidak dipublikasikan.

Idaini, S., Suhardi \& Kristanto, A.Y., 2009. Analisis Gejala Gangguan Mental Emosional Penduduk Indonesia. Majalah Kedokteran Indonesia, 59, pp.473-79

Lasisi, A.O \& Gureje, O (2013). Disability and Quality of Life among Elderly Persons with Self-Reported Hearing Impairment: Report from the Ibadan Study of Aging. International Journal of Otolaryngology and Head \& Neck Surgery, 2013, 2, 63-67

Minh HV, Huong DL, Wall S, Chuc NTK, Byass P (2010) Multilevel analysis of covariation in socioeconomic predictors of physical function and psychological well-being among older people in rural Vietnam. Geriatrics 10(7)
Moti, R.W \& McAuley, E (2010). Physical Activity, Disability, and Quality of Life in Older Adults. Phys Med Rehabil Clin N Am 21 (2010) 299-308

Qonitah N \& Isfandiari AM (2015) Hubungan antara IMT dan Kemandirian Fisik dengan Gangguan Mental Emosional pada Lansia. Jurnal Berkala Epidemiologi 3(1) Hal 1-11

Risdianto. (2009). Hubungan Dukungan Sosial dengan Kualitas Hidup Lanjut Usia di Desa Kembang Kuning Cepogo Boyolali. Skripsi Fakultas IImu Kesehatan Universitas Muhammadiyah Surakarta. Tidak dipublikasikan

Sutikno W (2015) Faktor-faktor yang berhubungan dengan gangguan kesehatan mental pada lansia: studi cross sectional pada kelompok jantung sehat surya group Kediri. Jurnal Wiyata, 2 (1)

Suyoko (2012) Faktor-faktor risiko yang berhubungan dengan gangguan mental emosional pada lansia di Jakarta (Analisis data riskesdas 2007). Skripsi.Universitas Indonesia.

WHO. (1996). The World Health Organization Quality of Life (WHOQOL)Bref. (online)http://www.who.int/entity/ substance_abuse/research_tools/en/ indonesian_whoqol.pdf. Diakses pada tanggal 5 Maret 2015

WHO. (2017). Mental health of older adults. (online) http://www.who.int/mediacentre/ factsheets/fs381/en/. Diakses 12 Februari 2017. 